\title{
ARTICLE \\ Operational interactions between the South American sea lion Otaria flavescens and purse seine fishing activities in northern Chile
}

Interacciones operacionales entre lobo marino común Otaria flavescens y actividades de pesca de cerco en el norte de Chile

\author{
Andrés González ${ }^{1}$, Rodrigo Vega ${ }^{1}$ and Eleuterio Yáñez ${ }^{2}$
}

\begin{abstract}
'Departamento de Evaluación de Pesquerías, División de Investigación Pesquera Instituto de Fomento Pesquero, Blanco 839, Valparaíso, Chile. andres.gonzalez@ifop.cl

${ }^{2}$ Escuela de Ciencias del Mar, Pontificia Universidad Católica de Valparaíso, P.O. Box 1020, Valparaíso, Chile

Resumen.- Se analizan variables temporales, espaciales, ambientales, ecológicas y pesqueras que contribuyen a la variación del número de lobos marinos comunes (Otaria flavescens) que interactúan con las faenas de pesca de cerco industrial de la flota que opera en el norte de Chile $\left(18^{\circ} 21^{\prime}-24^{\circ} 00^{\prime} \mathrm{S}\right)$. Observadores científicos fueron embarcados en buques cerqueros entre febrero 2010 y diciembre 2011. Los datos fueron modelados usando modelos lineales generalizados (MLG) y modelos lineales generalizados mixtos (MLGM). Los resultados muestran que la variabilidad en el número de lobos marinos atraídos por las operaciones de pesca para alimentarse o intentar hacerlo, se explica por las variables: Hora del lance, Distancia a las colonias de lobos más cercanas, Temperatura superficial del mar, Especie objetivo del lance, Latitud y Número de aves marinas en torno a la embarcación. Luego del análisis detallado de las variables significativas, se puede concluir que los principales mecanismos que estarían actuando sobre la interacción entre lobos marinos y la operación de pesca serían: 1) una estrategia utilizada por los otáridos para disminuir el estrés por calor en el período reproductivo (verano), saliendo al mar en horas de máxima radiación solar (al mediodía), lo que incrementa notablemente su presencia dentro del cerco en lances realizados a menos de 20 millas náuticas de las colonias y 2) durante períodos cálidos, la presencia de ondas Kelvin descendentes disminuiría la disponibilidad de anchoveta (Engraulis ringens) en la zona, lo que provoca que la flota reoriente sus operaciones hacia el jurel (Trachurus murphyi), recurso que generalmente se captura a mayores distancias de la costa y de las colonias, disminuyendo significativamente la interacción con los lobos marinos.
\end{abstract}

Palabras clave: Lobo marino común, Engraulis ringens, Índice ENSO Multivariado, Pesca de cerco

\begin{abstract}
This study analyzes temporal, spatial, environmental, ecological and fishing variables that contributed to variations in the number of South American sea lions (Otaria flavescens) that interacted with the industrial purse seine fishing operations in the north of Chile $\left(18^{\circ} 21^{\prime}-24^{\circ} 00^{\prime} \mathrm{S}\right)$. Scientific observers were placed onboard purse seiners vessels between February 2010 and December 2011. Data were modeled using generalized linear models (GLM) and generalized linear mixed models (GLMM). The results show that the variations in the number of sea lions attracted to fishing operations for feeding or attempting to feed on catches, depends on the following variables: Time of haul, Distance to the closest sea lion colony, Sea surface temperature, Target species of the haul, Latitude, and Number of seabirds circling the vessel. After detailed analysis of the significant variables, it can be concluded that the main mechanisms involved in the interaction between the sea lions and the fishing operations were: 1) a strategy used by the sea lions to decrease heat stress during the breeding period (summer) by entering the water when solar radiation is at its peak (around midday), thus notably increasing their presence within the nets during sets that are less than 20 nautical miles from the colonies; and 2) during warm periods the presence of downwelling Kelvin waves decreases the availability of anchovies (Engraulis ringens) in the area. This causes the fleet to change target species and focus on jack mackerel (Trachurus murphyi), which is generally captured further from the coast and the colonies, significantly decreasing the interaction with local sea lions.
\end{abstract}

Key words: South American sea lion, Engraulis ringens, Multivariate ENSO Index, Purse seine

\section{INTRODUCTION}

In areas where the coast is intensively utilized for harvesting and farming marine resources, there is a potential for interactions between fish-related industries and marine mammals (Bjørge et al. 2002). In this context interactions between pinnipeds and fishing operations have been widely documented in the international 
literature (Ainley et al. 1982, Bonner 1982, Northridge 1985, Hückstädt \& Antezana 2003, Goetz et al. 2008, Reyes et al. 2013). It is known that such interactions will occur in any place in the world where the distributions between pinnipeds and fishing activities overlap (Riedman 1990, Wickens 1995).

Purse seine fishing operations conducted in the north of Chile are denominated as Fishing Units XV, I and II for Chilean Administrative Regions for anchovy SUBPESCA $2011 \mathrm{a})^{1}$ and jack mackerel (SUBPESCA 2011b) ${ }^{2}$. In the last decade, landings of these fisheries have represented on average $23 \%$ of fish landings in Chile (SERNAPESCA 2002-2011) ${ }^{3}$. In the Administrative Regions mentioned, both species are caught by the same fleet, which comprises 66 purse seine fishing vessels, averaging $34 \mathrm{~m}$ of length (range between 22 and $44 \mathrm{~m}$ ), and $400 \mathrm{~m}^{3}$ of hold capacity (range between 140 and $670 \mathrm{~m}^{3}$; Bernal et al. $2010)^{4}$. The operations of this fleet cover an extensive area from the port of Arica in the north $\left(18^{\circ} 21^{\prime} \mathrm{S} ; 70^{\circ} 19^{\prime} \mathrm{W}\right)$ to Antofagasta in the south $\left(23^{\circ} 38^{\prime} \mathrm{S} ; 70^{\circ} 24^{\prime} \mathrm{W}\right)$, and reaching 90 nautical miles from the coast (SUBPESCA 2011a). This area sustains a large population of South American sea lions (Otaria flavescens), with population reaching 59,657 individuals distributed over 44 breeding and haul-out colonies, thus representing $43.6 \%$ of the total population of this species in Chile (Bartheld et al. 2008).

Though sea lions are considered generalist predators, located on the upper levels of the food web (Beverton 1985), in the study area the South American sea lion feeds mainly on anchovy (Sielfeld et al. 1997, Sielfeld 1999, Arias-Schreiber 2003), which might lead to its interaction with the purse seine fishing fleet that targets this species.

Two types of interaction can be defined between marine mammals with fishing activities: a biological (indirect) interaction due to competition for food, and an operational (direct) interaction due to predation, where the animals enter the purse seine nets to feed, occasionally leading to their capture in the net. In general, operational interactions negatively affect the fishers by disturbing the fishing operation (increased work time), reducing catches and in some cases damaging fishing gear (Beverton 1985, Wickens 1995, Read 2008). The operational interactions can also be negative for marine top predators due to the possibility of the animals coming into direct contact with the fishing system, leading to injury and even death (Oliva et al. 2003, Read 2008, Fertl 2009, Reyes et al. 2013).

The effects of the interaction on the pinnipeds (seals, sea lions and walrus) can be positive, due to the obvious advantages of preying on a concentrated food source that is easy to access (Hückstädt \& Antezana 2003). The fishing operations concentrate the food source; leading to a reduction in the amount of energy the sea lions spend in feeding (Fertl 2009).

The main operational interactions between sea lions and fisheries reported in Chile are predation of catch, bycatch and incidental mortality of sea lions (Hückstädt \& Antezana 2003, Sepúlveda et al. 2007, Reyes et al. 2013), while the damage to fishing gear is important in artisanal fisheries (Sepúlveda et al. 2007). Hückstädt \& Antezana (2003) reported an average interaction of 21 sea lions per set while Reyes et al. (2013), working with the trawling industrial fleet that operates in the south-central Chile indicates a catch rate of 1.2 sea lion/trawl $l^{-1}$ and a mortality of $14.6 \%$.

Bycatch records are used to determine the extent (temporal, spatial, by species) and magnitude (number of individuals per species) of these events, while studying the interactions, abundance of species that interact with fisheries, environmental and operational data are used to understand the nature of these interactions, and the importance of the factors that influence the level of these interactions. This is important for identifying specific mitigation solutions for the particular fishery (ACAP 2012).

Considering the importance of understanding the main mechanisms underlying the interaction processes between non-target species and fishing operations in the context of an ecosystem approach to fisheries management (FAO 2003), the current study aims to analyze different factors

\footnotetext{
${ }^{1}$ SUBPESCA. 2011a. Cuota global anual de captura para las unidades de pesquería de anchoveta y sardina española, regiones XV, I y II, año 2012. Informe Técnico (R Pesq), 108 pp. Subsecretaría de Pesca y Acuicultura, Valparaíso.

${ }^{2}$ SUBPESCA. 2011b. Cuota global anual de captura de jurel, para las unidades de pesquería de la XV-II, III-IV, V-IX y XIV-X regiones, año 2012. Informe Técnico (R Pesq), 129 pp. Subsecretaría de Pesca y Acuicultura, Valparaíso.

${ }^{3}$ SERNAPESCA. 2002-2011. Anuarios estadísticos de pesca. Servicio Nacional de Pesca, Ministerio de Economía, Fomento y Reconstrucción, Chile. <http://www.sernapesca.cl/>

${ }^{4}$ Bernal C, A González, J Azócar, V Escobar, JC Saavedra, Z Young, O Guzmán, C Vera \& M González. 2010. Programa de Seguimiento de las Principales Pesquerías Nacionales. Informe Final Proyecto: Investigación Programa Observadores Científicos, 2010. Instituto de Fomento Pesquero, 121 pp.
} 
(temporal, environmental, spatial, ecological and fishing) which may contribute to variations in the number of South American sea lions that interact with the industrial purse seine fleet operating in the north of Chile.

\section{Materials AND METHODS}

\section{Data collection}

The study area comprises the waters of the Chilean Exclusive Economic Zone from the port of Arica (18 $21^{\prime} \mathrm{S}$; $\left.70^{\circ} 19^{\prime} \mathrm{W}\right)$ to the south of the region of Antofagasta $\left(23^{\circ} 38^{\prime} \mathrm{S} ; 70^{\circ} 24^{\prime} \mathrm{W}\right)$. The data used were obtained by scientific observers (SO) from the Instituto de Fomento Pesquero (IFOP; Fisheries Development Institute), as part of the North Zone Pelagic Fishing Situation Research Program. Information was collected by observers aboard vessels from 258 hauls over 166 trips performed between February 2010 and December 2011. This observation effort (166 trips) represented $1 \%$ of the total effort applied by the fleet in the study period (Gabriela Böhm, pers. comm.). All the observations recording by $\mathrm{SO}$ were made during daylight sets. The SO recorded the date, time, and geographic position of all sets, as well as sea surface temperature (SST), target species and catch per species (in tons). A proxy of ship size, the storage capacity (ton) was also taken. During each haul, the SO counted the number of sea lions attracted by fishing operations for feeding or attempting to feed on catches. The number of other purse seine fishing vessels operating nearby was also recorded, where distance of observation is depending of sighting conditions (radius between 5 and 10 nautic miles). In order to count the sea lions, the protocol used was developed for the IFOP scientific observer program

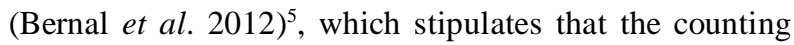
should be conducted on daylight sets, on the winch side (starboard), maintaining a fixed counting location at the moment the net is pulled onto the vessel, and in a $250 \mathrm{~m}$ hemisphere centered alongside the vessel (Melvin et al. 2009, Bernal et al. 2012). The time of the haul was used to estimate the intensity of the solar radiation, assuming that the level of intensity increases from dawn and reaches a maximum around midday, and then decreasing until sunset (Campagna \& LeBoeuf 1988). Abundance and geographic positions of sea lions colonies data recorded on February 2007 by Bartheld et al. (2008) was used to calculate size and geographic position of the sea lion colony centers (Fig. 1). A sea lion colony center was defined as a group of colonies within a radius of 10 nautical miles around the biggest colony of the group, where the geographic position of the biggest colony was chosen as the location of the center, and the size of the center was defined as the sum of the individual groups of colonies. The computer software packages PBSmapping, RODBC and R language RColorBrewer (R Development Core Team 2006) were used to calculate the distance in nautical miles $(\mathrm{nm})$ from the position at the start of the set and the position to the closest colony center. Finally, the Multivariate ENSO (El Niño Southern Oscillation) Index (MEI) was also included in the analysis. This index describes the atmospheric and oceanic conditions in the tropical Pacific Ocean $\left(30^{\circ} \mathrm{S}-30^{\circ} \mathrm{N}\right)$, adjusted seasonally with regard to the reference period 1950-1993 (Wolter \& Timlin 1998) ${ }^{6}$. Negative values of the standardized MEI represent cold conditions, while positive values represent warm conditions). All the aforementioned factors were input into the model as independent variables. The response variable of the model was defined as the number of South American sea lion feeding or attempting to feed on the catch from each haul (Table 1).

\section{Statistical analysis}

Regression analysis was performed using generalized linear models (GLM) and generalized linear mixed models (GLMM). The response variable, the number of sea lions interacting with fishing operations, was given by counting data that was therefore discrete and nonnegative. The GLM and GLMM allowed increased flexibility in the assumptions compared with traditional regression techniques, allowing direct specification of the error distribution (Gill 2001) and integration of continuous and categorical data into one single setting. The GLMM cover the dependence between the observations, incorporating two types of effects: direct effects (fixed effects), which are the explanatory variables; and the indirect effects (random effects), which include a set number of observations (hauls). The first represent the mean or 'typical' level of the response variable and the second represent the specific deviations by grouped

\footnotetext{
${ }^{5}$ Bernal C, J Azócar, A González, L Ossa, V Escobar, M San Martín, JC Saavedra, C Villouta, R Bello \& J Castillo. 2012. Programa de Seguimiento de las Principales Pesquerías Nacionales. Informe Final Proyecto: Investigación Programa Observadores Científicos, 2012. Instituto de Fomento Pesquero, Valparaíso, $169 \mathrm{pp}$.

${ }^{6}<$ www.cdc.noaa.gov/people/klaus.wolter/MEl/mei.html >
} 


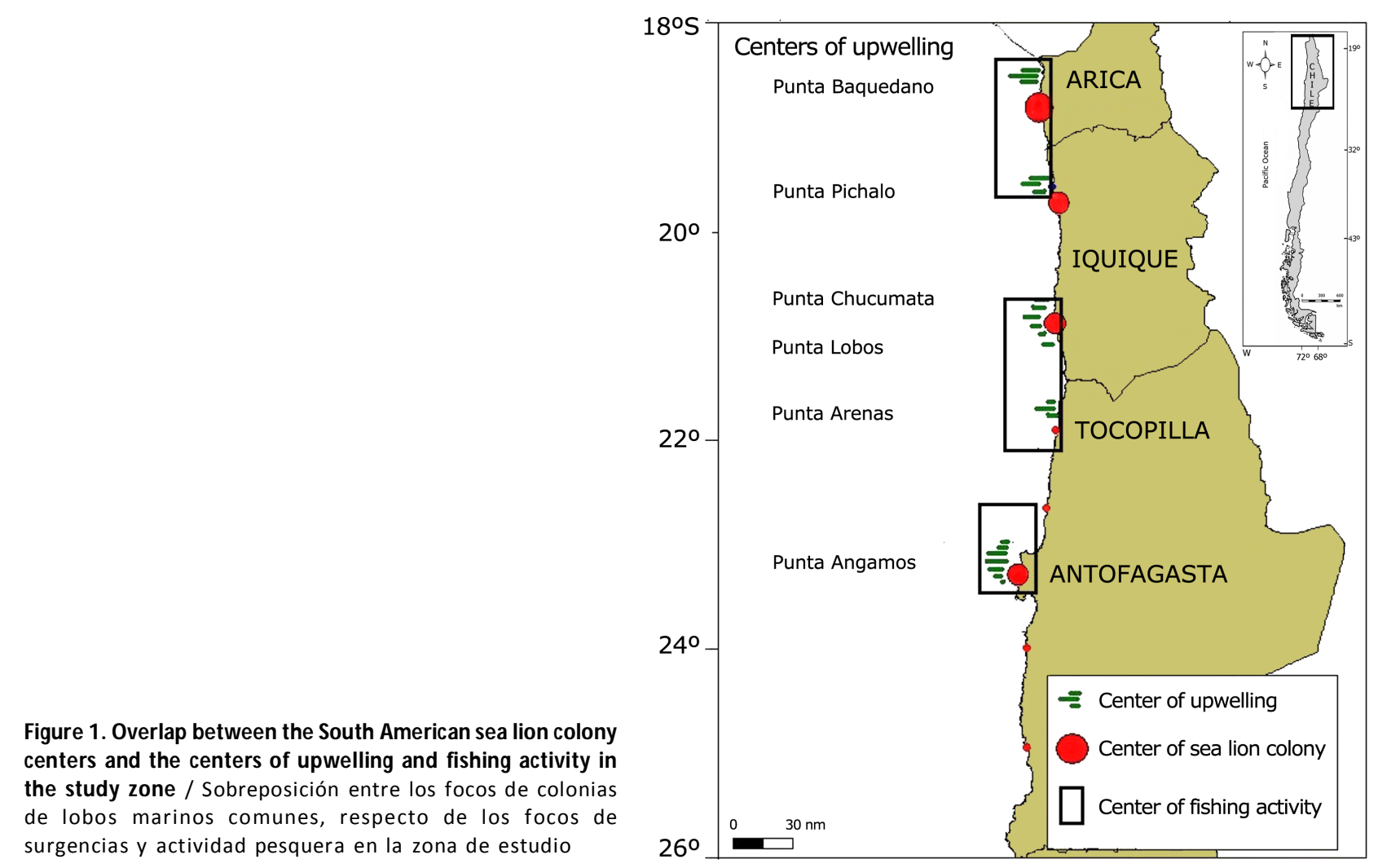

Table 1. Temporal, spatial, environmental, ecological and fishing variables included in the analysis / Variables temporales, espaciales, ecológicas y pesqueras incluidas en los análisis

\begin{tabular}{lll}
\hline \multicolumn{1}{c}{ Independent variables } & \multicolumn{1}{c}{ Classes } & Description \\
\hline Temporal & & \\
Year (annual) & $2010-2011$ & Each year as category \\
Season (seasonal) & Summer-Autumn-Winter-Spring & Each season as category \\
Spatial & & \\
Latitude (lat) & Continuous variable & Decimal degrees \\
Longitude (lon) & Continuous variable & Decimal degrees \\
Environmental & & \\
Sea surface temperature (sst) & Continuous variable & Centigrade \\
Time of haul (time) & Continuous variable & Decimal number \\
MEI (mei) & Llnmf-Tt-Eenmf* & Each condition as category \\
Ecological & & \\
Presence of seabirds (paves) & Yes-No & Discrete factor with two categories \\
Number of seabirds (naves) & Continuous & Whole number \\
Number of species of seabirds (nsps) & Continuous & Whole number \\
Size of colony centers (abund) & A-M-B** & Discrete factor with three categories \\
Distance to closest colony center (discol) & Continuous variable & Nautical miles \\
Reproduction period (reprod) & Inside-Outside*** & Discrete factor with two categories \\
Fishing & & \\
Number of vessels (nbuques) & Continuous variable & Whole number \\
Storage capacity (cbod) & Continuous variable & Cubic meters \\
Target species (spobj) & Anchovy-Jack mackerel & Discrete factor with two categories \\
\hline
\end{tabular}

The code for each variable is shown in brackets

* Lnmf=La Niña moderate to strong; T=transition; Enmf=E1 Niño moderate to strong

** $\mathrm{A}=$ high ( $>8,000$ individuals); $\mathrm{M}=$ medium (2,000-8,000 individuals); $\mathrm{B}=$ low $(<2,000$ individuals $)$

$* * *$ Inside $=$ during the reproduction period; Outside $=$ outside the reproduction period 
level, which are incorporated into the marginal distribution (Bates 2010). In addition to the GLM and GLMM analyses, generalized additive models (GAM) were also fit in order to allow the exploration of non-linear functional relations between the response variable and the independent variables. The GAM replaces the linear predictor of the GLM with an additive predictor allowing the combination of linear with non-linear and nonparametric relations (Hastie \& Tibshirani 1990). Before adding the independent variables into the model, the absence of co-linearity was checked and the co-variables were put onto the same measurement scale by a process of standardization, in order to be able to compare their respective estimated coefficients. Poisson and negative binomial distributions were used to model the number of sea lions interacting with fishing operations as a function of the explanatory variables, because they are the best discrete probability distributions for describing count data (Crawley 2013). The models were first built with a Poisson distribution. After checking and confirming overdispersion, negative binomial distribution was used instead (Passadore et al. 2015). To choose the best-fitting model, explanatory variables were selected manually by deletion from a complex initial model (backward). Analysis of variance (ANOVA) was used to compare the resulting model with the previous model of the simplication procedure. When the removal of a variable produced a significant increase in model's deviance, that variable was considered statistically significant and, thus, returned and retained in the model. When the removal produced nonsignificant change in deviance, the variable was left out of the model (Passadore et al. 2015). Variables were sequentially removed until the model contained only significant terms; that model was considered as the minimum adequate model (Crawley 2013).

The following statistics packages were used for these analyses: lme4 (GLMM; Bates 2010), mgcv (GAM; Wood 2008), and MASS (GLM; Venables \& Ripley 2002), available in $\mathrm{R}$ language ( $\mathrm{R}$ Development Core Team 2011). The Akaike Information Criterion (AIC) was used to select the best model. AIC is a measure of the goodness of fit including parsimony. The model determined by parsimony is defined as a model that fits data and so it includes few parameters needed (Burnham \& Anderson 2002).

\section{Results}

The average number ( \pm S.D.) of sea lions that were seen to interact over a total of 258 fishing sets was $55( \pm 56)$ per haul, in a range of 0 to 290 . A preliminary analysis of the data allowed the exclusion of some variables, such as Longitude and Distance from the set to the coastline, since both were highly correlated with the variable Distance to closest colony center.

The final model showing the best fit was the GLMM that included the random effect of Fishing trip (IdViaje), within the random effect Fishing vessel (IdBuque). Due to the nested structure of the data, mixed modeling techniques were applied to allow the inclusion of correlation between observations of the same grouping level (Zuur et al. 2009). In our case, the hauls conducted during the same fishing trip are probably more related to each other than to hauls from other trips, and fishing trips of the same vessel are also more connected to one another than to trips of other ships.

When analyzing the abundance of sea lions interacting with the purse seiners in relation to explanatory variables, the model indicated the significant effect of Distance to closest colony center, SST, Latitude, Number of vessels operating in the area, Number of seabirds and Time of haul (Table 2). The number of sea lions interacting with the purse seiners tends to decrease when the number of vessels increased (Fig. 2a), and when fishing operations were performed further from the centers of the colonies (Fig. 2b). Moreover, sea lions showed a major level of interactions in the northern part of the study area and then decrease their number as we move south to finally present a secondary peak in the southern part of the area (Fig. 2c). Higher levels of abundance of sea lions attending

Table 2. Result of the fit of the GLMM model for the number of South American sea lions interacting with purse seine fishing operations in northern Chile / Resultado del ajuste del MLGM para el número de lobos marinos comunes interactuando con las operaciones de pesca de cerco en el norte de Chile

\begin{tabular}{lrrl}
\hline Co-variable & D.F. & $\begin{array}{c}\chi^{2}- \\
\text { value }\end{array}$ & $P$-value \\
\hline Year & 1 & 2.94 & 0.0864 \\
Season & 3 & 1.01 & 0.7998 \\
Reproduction period & 1 & 0.12 & 0.7310 \\
Time of haul & 2 & 309.39 & $<2.2 \mathrm{e}-16^{* * *}$ \\
Distance to closest colony center & 1 & 86.23 & $<2.2 \mathrm{e}-16^{* * *}$ \\
Latitude & 1 & 29.48 & $5.8 \mathrm{e}-08^{* * *}$ \\
Number of vessels & 1 & 0.08 & 0.7839 \\
Storage capacity & 1 & 1.58 & 0.2076 \\
Sea surface temperature & 1 & 57.36 & $3.6 \mathrm{e}-14^{* * *}$ \\
Number of seabirds & 1 & 14.33 & $1.5 \mathrm{e}-04^{* * *}$ \\
Presence of seabirds & 1 & 1.28 & 0.2579 \\
Number of seabird species & 1 & 3.64 & 0.0565 \\
Target species & 1 & 44.31 & $2.7 \mathrm{e}-11^{* * *}$ \\
MEI & 2 & 0.06 & 0.9683 \\
Size of colony center & 2 & 0.32 & 0.8502 \\
Number of vessels:MEI & 3 & 238.16 & $<2.2 \mathrm{e}-16^{* * *}$ \\
Distance to colony center:Time of haul & 2 & 173.38 & $<2.2 \mathrm{e}-16^{* * *}$ \\
Target species:MEI & 2 & 71.70 & $1.2 \mathrm{e}-15^{* * * *}$ \\
\hline
\end{tabular}

D.F.: degrees of freedom 

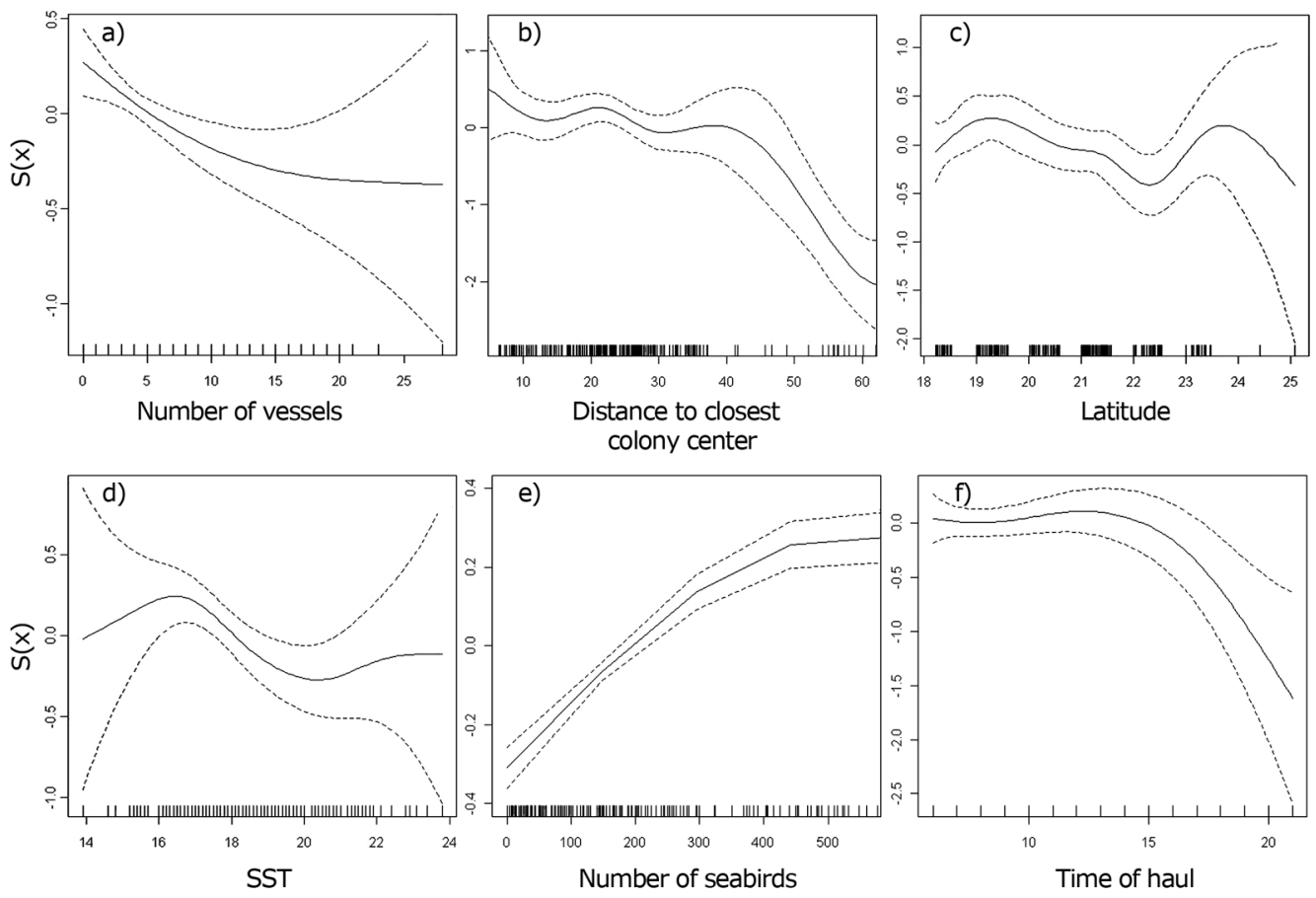

Figure 2. Graphs of the GAM fit. a) Number of vessels, b) Distance to closest colony center, c) Latitude, d) SST, e) Number of seabirds, f) Time of haul; $\mathbf{S}(\mathbf{x})$ represents the smoothed spline function of the predictor variable / Representaciones gráficas del ajuste del MAG. a) Número de buques, b) Distancia al centro de colonias más cercana, c) Latitud, d) Temperatura superficial del mar, e) Número de aves marinas, f) Hora del lance; $\mathrm{S}(\mathrm{x})$ representa la función spline suavizada de la variable predictora indicada

the fishing operations were observed between 16 to $17^{\circ} \mathrm{C}$ of SST, and tends to decrease when the SST increased (Fig. 2d). Furthermore, the number of sea lions interacting increases according as seabird abundance attending purse seine vessels increases (Fig. 2e). Time of haul showed higher values of sea lion interaction around midday and early afternoon (Fig. 2f). Finally, the level of interaction of sea lions was significantly higher (Wilcoxon rank sum test; $P$-value $<0.001$; Fig. 3 ) when the fleet was capturing anchovy (mean 59 sea lions per set), regarding fishing operations on jack mackerel (mean 29 sea lions per set). The operation over anchovy was more coastal (mean $20 \mathrm{~nm}$ from coast), that over jack mackerel (mean 34 $\mathrm{nm}$ from coast).

High significance was found in the interaction of the variables Distance from haul to the closest colony center and Time of haul, where an important increase in the number of sea lions was observed around midday during sets that took place less than $20 \mathrm{~nm}$ from a colony center during the breeding period, from mid-December to midMarch (Fig. 4a). This effect disappears in nonreproductive period, where were observed similar levels

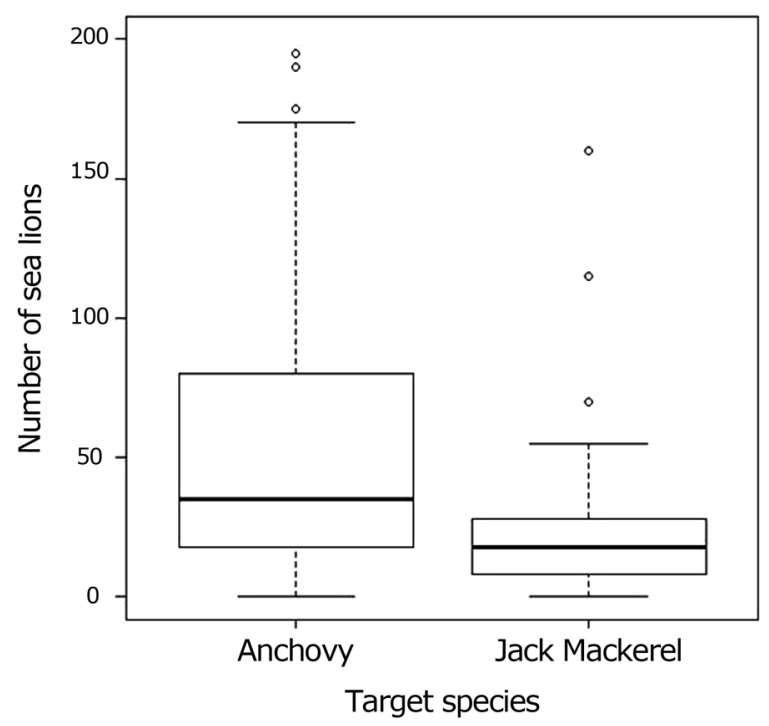

Figure 3. Boxplot of the number of sea lions interacting with fishing differentiated by target species / Box plot del número de lobos marinos comunes interactuando según especie objetivo 
a)

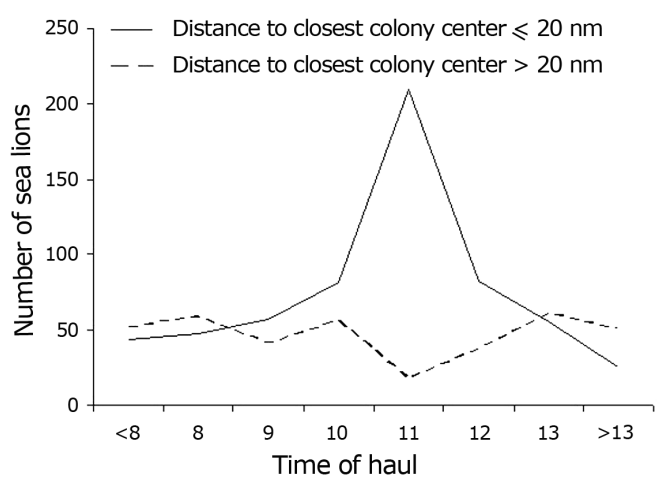

b)

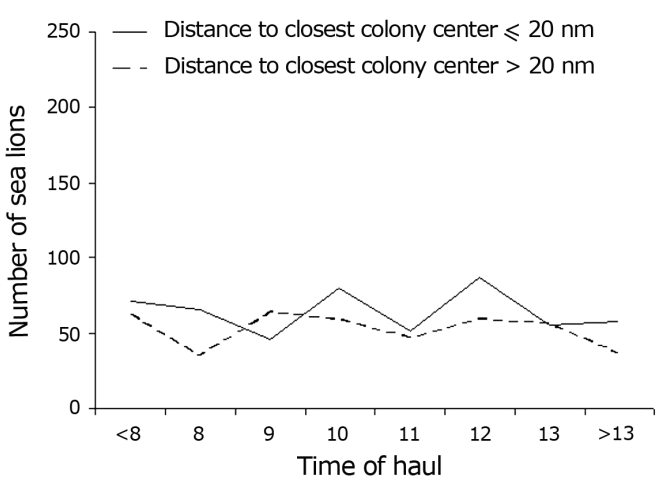

Figure 4. Graphs of the interaction between the Distance to the closest colony center and Time of haul: a) During breeding season, b) During non-breeding season / Representación gráfica de la interacción entre Distancia al foco de colonias más cercana y Hora del lance. a) Periodo reproductivo, b) Periodo no reproductivo

a)

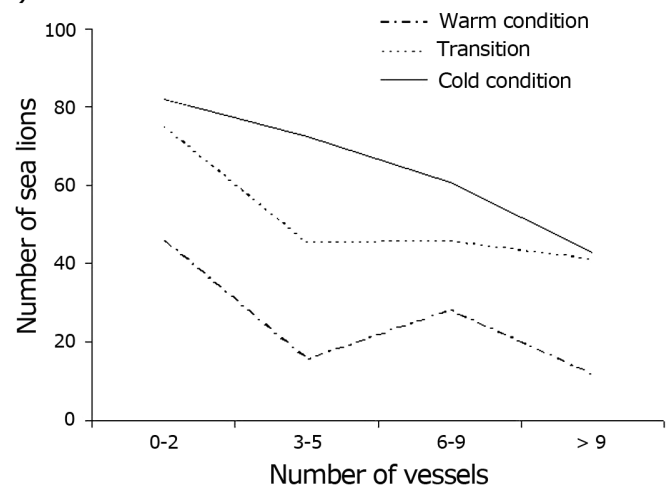

b)

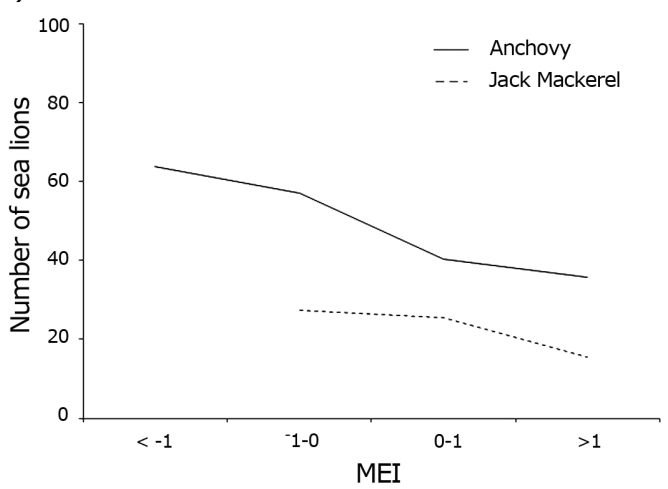

Figure 5. Graphs of interactions based on the GLMM fit. a) Number of vessels-MEI, b) Target species-MEI / Representaciones gráficas del ajuste del MLGM. a) Número de buques-MEI, b) Especie objetivo-MEI

in the abundance of sea lions during sets that took place to less and more than $20 \mathrm{~nm}$ from a colony center (Fig. $4 b)$.

The individual contribution of the Number of vessels operating in the area and MEI was not significant since a large part of its effect is already considered in the interaction between these variables, which was highly significant, showing an escalated effect on the response variable for different levels of MEI (Table 2; Fig. 5a). The interaction between target species and MEI showed that the abundance of sea lions decreased as we move from cold conditions (negative values of the standardized MEI), to warm conditions (positive values of the standardized MEI), for both target species (Fig. 5b).

\section{Discussion}

The association of the sea lions with coastal fisheries has been recorded previously in virtually all areas where breeding and non-breeding colonies occur (Bastida et al. 2007). Feeding of marine mammals in association with fishing operations is a learned behavior leading to the increase of the number of individuals seeking out fishing systems to find food easily. According to Königson et al. (2006), a prior feeding experience may encourage sea lions to return to feeding areas where they have been successful. It has been suggested that this type of feeding behavior is transferred from generation to generation by observation and participation (Fertl \& Leatherwood 1997).

In our study, the average number of sea lions interacting with purse seine operations was 55 per haul, which is more than the figure reported by Hückstädt \& Antezana 
(2003) for the purse seine fleet targeting jack mackerel in the VIII region of Chile ( $\left.36^{\circ} 00^{\prime} \mathrm{S}-38^{\circ} 30^{\prime} \mathrm{S}\right)$, which reported an average of 21 individuals per haul (range: 0-50). This difference may be explained in part by the difference in the size of sea lion populations in each zone. For the area from Arica to Antofagasta the population has been estimated at 59,657 individuals (Bartheld et al. 2008), while in the area from Cobquecura to Mocha Island in the VIII region, this value is only 8,189 individuals (Sepúlveda et al. 2011). In fact, in the former area there are colonies (Punta Lobos, Punta Piojo and Bandurrias del sur) with populations that exceed the total estimated population for the entire VIII region (Bartheld et al. 2008). Another factor that can explain the observed differences is the fact that sea lion in the south-central area of Chile interact mainly with coastal purse seine fleet of small pelagic, in fact Muñoz et al. (2013) found Chilean herring (Strangomera bentincki) as the main food items of sea lions in this area.

The result of the variable Distance to the closest colony center is in agreement with the findings of other studies (Szteren \& Páez 2002, Smith \& Baird 2005, Sepúlveda et al. 2007). This inverse correlation is partly explained by the fact that the feeding areas of the sea lions are fundamentally shallow-coastal waters (Hevia 2013, Hückstädt et al.2014), and also the females need to remain close to their offspring (Smith \& Baird 2005). The distance from the set to the colony center also interacted significantly with the variable Time of haul, which is an indicator of sunlight intensity, showing an increased number of sea lions in sets conducted around midday and at least $20 \mathrm{~nm}$ from the colony centers during breeding period. This effect disappears in non-reproductive period, where were observed similar levels in the abundance of sea lions during sets that took place to less and more than $20 \mathrm{~nm}$ from a colony center. This can be understood as part of a strategy used by the animals to reduce heat stress during breeding periods by entering the sea before the sun reaches its highest point in the sky (midday) and returning to land in the late afternoon, thus decreasing their exposure to heat during the hours around midday (Soto et al. 2006). According to Campagna \& LeBoeuf (1988), this strategy is a behavioral adaptation seen in otariids living in tropical and subtropical areas, which are exposed to intense solar radiation and high air temperatures during the breeding period. This behavior has been observed in females in Peru (Soto et al. 2006) and young individuals in Chile (Sepúlveda et al. 2012).
One of the main sources of variation in the Humboldt Current System derives from coastally trapped Kelvin Waves (KW) which are originates by wind variations in the central and western equatorial Pacific (Pizarro et al. 2001), where the type of wind (eastern or western winds) determines whether an equatorial $\mathrm{KW}$ will upwell or downwell the thermocline often tens of meters (Bertrand $e t$ al. 2008). The KW are coastally trapped by the force of the rotation of the earth (Coriolis) along the continental platform or shelf (Clarke 1983, 1992). During a warm period the KW are in downwelling conditions, while during a cold period the KW are in upwelling conditions (Chavez et al. 2008).

The behavior of the co-variable MEI (one month delayed) showed that the number of sea lions interacting with purse seine fishing operations tends to decrease when the environment moves from cold (negative standardized values) to warm condition (positive values). According to Barber \& Chavez (1983), during warm condition the anchovy tends to move to greater depths, below the warmer and less productive surface waters (Arntz \& Fahrbach 1996), thus decreasing their availability to purse seine fishing nets (Niquen \& Bouchon 2002, Bertrand et al. 2004). This causes the fleet to alter the focus of the operations to the jack mackerel, which is generally sought further from the coast and the sea lion colonies.

It has also been observed that during warm condition the abundance of the anchovy decreases and they move to greater depths, which means that the sea lions must expend more energy per unit of prey consumed, which would explain why the anchovy become less relevant to their diets during this period, where they are replaced by demersal species (Soto et al. 2006). The variation in the availability of anchovy induced by warm condition effects, affects higher predators such as fishing vessels and sea lions, which modify their target species in adverse conditions. Sets targeting anchovy went from 97\% during cold condition to $48 \%$ during warm condition. This causes a decrease in the interaction with sea lions, though this can also be explained by the high significance of interaction between variables such as target species and MEI, or between number of vessels and MEI, where in the latter case the number of vessels has a clear mitigating effect on intraspecific competition of sea lions during cold condition, by decreasing the presence of the animals with the increase in the number of vessels operating in the zone. This effect disappears during warm condition due to the decrease in the number of sea lions interacting with the fishing operations. 
The co-variable SST showed an inverse relation with the number of sea lions indicating that the foraging activities of these marine mammals is related to coastal upwelling, more than to oceanic factors, which is explained by the distribution of their main prey, the anchovy, a species that is associated with coastal upwelling (Swartzman et al. 2008). In fact, $84 \%$ of the catches of anchovy are obtained less than 20 nautical miles from the coast (Böhm et al. 2012) ${ }^{7}$.

The number of seabirds present in the fishing operations was also highly significant, with an increase in the number of sea lions along with the increase in the number of marine birds. This correlation can be explained in two ways; firstly, most seabirds registered during the study are coastal species (mainly seagulls, pelicans, boobies and cormorants), whose numbers tend to decrease as the fishing activities move further from the coast, and secondly, it is known that pinnipeds are predators with highly developed cognitive abilities (Gentry 2002), meaning that they are able to associate a higher number of seabirds around a fishing vessel with easier access to a large amount of potential prey concentrated in a small area (Hückstädt \& Antezana 2003).

The behavior seen in the response variable respecting to the co-variable Latitude is related to the pattern shown by the colony sizes measured by Bartheld et al. (2008), i.e., larger colonies present in the northern part of the study area $\left(19^{\circ} \mathrm{S}\right)$ with a continual decrease as we move further south, reaching minimum values around the port of Tocopilla $\left(22^{\circ} 04^{\prime} \mathrm{S} ; 70^{\circ} 12^{\prime} \mathrm{W}\right)$, and then resurging

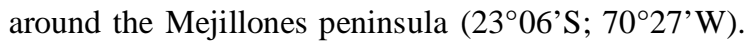

Further information of this type regarding the artisanal and industrial purse seiners that operate in the southcentral part of Chile should also be gathered, and actions necessary to free animals captures must also be studied and defined.

\section{ACKNOWLedgments}

We thank to Instituto de Fomento Pesquero and North Zone Pelagic Fishing Situation Research Program, for providing the data used in this study. We also thank Mr. Raul Ojeda and the Scientific Observers for their valuable contribution to the collection of data onboard. We also would like to thank the anonymous reviewers for providing critical suggestions resulting in significant improvements of the manuscript.

\section{LITERATURE CITED}

ACAP. 2012. Minimum data requirements for monitoring seabird bycatch. Western and Central Pacific Fisheries Commission, Kolonia WCPFC-SC8-2012/B-WP-07: 1-17. <https://www.wcpfc.int/system/files/WCPFC-TCC 82012-OP02 ACAP-Minimum-data-requirements-seabirdbycatch.pdf>

Arias-Schreiber M. 2003. Prey spectrum and feeding behaviour of two sympatric pinnipeds (Arctocephalus australis and Otaria flavescens) in relation to the 1997-98 ENSO in southern Peru. M.Sc. Thesis, Faculty of Biology and Chemistry, University of Bremen, Bremen, $59 \mathrm{pp}$.

Ainley D, H Huber \& K Bailey. 1982. Population fluctuations of California sea lions and the Pacific whiting fishery off Central California. Fishery Bulletin 80(2): 253-258.

ArntzWE \& E Fahrbach. 1996. ElNiño: experimento climático de la naturaleza, 312 pp. Fondo de Cultura Económica, México.

Barber RT \& FP Chavez. 1983. Biological consequences of El Niño. Science 222: 1203-1210.

Bartheld J, H Pavés, C Manque, C Vera \& D Miranda. 2008. Cuantificación poblacional de lobos marinos en el litoral de la I a IV Región. Informe Final Proyecto FIP 2006-50: 1-124. <http://www.fip.cl/FIP/Archivos/pdf/ informes/inffinal\%202006-50.pdf>

Bastida R, D Rodríguez, E Secchi \& V da Silva. 2007. Mamíferos acuáticos de Sudamérica y Antártida, 366 pp. Vázquez Mazzini Editores, Buenos Aires.

Bates D. 2010. lme4: Mixed-effects modelling. Springer, New York. 〈www://lme4.r-forge.r-project.org/book>

Bernal P, F Robles \& O Rojas. 1983. Variabilidad física y biológica en la región meridional del sistema de corrientes Chile-Perú. FAO Fisheries Report 291(3): 683-711.

Bertrand A, M Segura, M Gutiérrez \& L Vásquez. 2004. From small-scale habitat loopholes to decadal cycles: a habitat-based hypothesis explaining fluctuation in pelagic fish populations off Peru. Fish and Fisheries 5: 296-316.

Bertrand S, B Dewitte, J Tam, E Díaz \& A Bertrand. 2008 Impacts of Kelvin wave forcing in the Peru Humboldt Current system: Scenarios of spatial reorganizations from physics to fishers. Progress in Oceanography 79: 278-289.

${ }^{7}$ Böhm MG, C Hernández, G Perez, E Díaz, L Ossa, H Reyes, R Aravena, Z Young, F Cerna, V. Bocic, C Machuca, L Muñoz \& M Troncoso. 2012. Programa de seguimiento del estado de situación de las principales pesquerías nacionales: Asesoría integral para la toma de decisiones en pesca y acuicultura, 2011, actividad 1: Recursos pelágicos Zona Norte, Informe Final, Convenio SUBPESCA-IFOP, Valparaíso, 265 pp. 
Beverton R. 1985. Analysis of marine mammal-fisheries interaction. In: Beddington JR, RJH Beverton \& DM Lavigne (eds). Marine mammals and fisheries, pp. 3-33. George Allen \& Unwin, London.

Bjørge A, T Bekkby, V Bakkestuen \& E Framstad. 2002. Interactions between harbour seals, Phoca vitulina, and fisheries in complex coastal waters explored by combined Geographic Information System (GIS) and energetics modelling. ICES Journal of Marine Science 59(1): 29-42.

Bonner WN. 1982. Seals and man: A study of interactions, 170 pp. Washington Sea Grant Publication, University of Washington Press, Seattle.

Burnham K \& D Anderson. 2002. Model selection and multimodal inference: A practical information theoretic approach, 488 pp. Springer-Verlag, New York.

Campagna C \& BJ LeBoeuf. 1988. Thermoregulatory behaviour of southern sea lions and its effect on mating strategies. Behaviour 107: 73-90.

Chavez FP, A Bertrand, R Guevara-Carrasco, P Soler \& J Csirke. 2008. The northern Humboldt Current system: brief history, present status and a view towards the future. Progress in Oceanography 79: 95-105.

Clarke AJ. 1983. The reflection of equatorial waves from oceanic boundaries. Journal of Physical Oceanography 13: 1183-1207.

Clarke AJ. 1992. Low-frequency reflection from a nonmeridional eastern ocean boundary and the use of coastal sea level to monitor eastern Pacific equatorial Kelvin waves. Journal of Physical Oceanography 22: 163-183.

FAO. 2003. Fisheries management. The ecosystem approach to fisheries. FAO Technical Guidelines for Responsible Fisheries 4(Suppl. 2): 1-112.

Fertl D \& S Leatherwood. 1997. Cetacean interactions with trawls: A preliminary review. Journal of Northwest Atlantic Fishery Science 22: 219-248.

Fertl D. 2009. Fisheries, interference with. In: Perrin WF, B Wüarsig \& JGM Thewissen (eds). Encyclopedia of marine mammals, pp. 439-443. Academic Press, New York.

Gentry RL. 2002. Eared seals. In: Perrin WF, B Wüarsig \& JGM Thewissen (eds). Encyclopedia of marine mammals, pp. 348-352. Academic Press, New York.

Gill J. 2001. Generalized linear models: A unified approach. Quantitative Applications in the Social Sciences 134: 1112. Sage University Papers, Thousand Oaks.

Goetz S, M Wolf, W Stotz \& M Villegas. 2008. Interactions between the South American sea lion (Otaria flavescens) and the artisanal fishery off Coquimbo, northern Chile. Journal of Marine Science 65: 1739-1746.

Hastie T \& RJ Tibshirani. 1990. Generalized additive models, 559 pp. Chapman \& Hall, London.
Hevia K. 2013. Áreas de alimentación del lobo marino común Otaria flavescens en la zona norte de Chile. Tesis de Ingeniería Ambiental, Facultad de Ciencias, Universidad de Valparaíso, Valparaíso, 93 pp.

Hückstädt LA \& T Antezana. 2003. Behaviour of the southern sea lion (Otaria flavescens) and consumption of the catch during purse-seining for jack mackerel (Trachurus symmetricus) off central Chile. ICES Journal of Marine Science 60: 1003-1011.

Hückstädt LA, RA Quiñones, M Sepúlveda \& DP Costa. 2014. Movement and diving patterns of juvenile male South American sea lions off the coast of central Chile. Marine Mammal Science 30: 1175-1183.

Königson SJ, KE Lündström, MMB Hemmingsson, SG Lunneryd \& H Westerberg. 2006. Feedings preferences of harbour seals (Phoca vitulina) specialized in raiding fishing gear. Aquatic Mammals 32: 152-156.

Melvin EF, C Heinecken \& TJ Guy. 2009. Optimizing tori line designs for pelagic tuna longline fisheries: South Africa. Report of work under special permit from the Republic of South Africa. Department of Environmental Affairs and Tourism, Marine and Coastal Management, Pelagic and High Seas Fishery Management Division. <http:// www.wsg.washington.edu/mas/resources/seabird.html>

Muñoz L, G Pavez, RA Quiñones, D Oliva, M Santos \& M Sepúlveda. 2013. Diet plasticity of the South American sea lion in Chile: stable isotope evidence. Revista de Biología Marina y Oceanografía 48: 613-622.

Northridge S. $\mathbf{1 9 8 5}$. World review of interactions between marine mammals and fisheries. FAO Fisheries Technical Paper 251: 1-234.

Ñiquen M \& M Bouchon. 2002. Interactions between distribution and concentration of main pelagic resources in Peruvian waters during 1983-2001. Investigaciones Marinas 30: 196-197.

Oliva D, W Sielfeld, L Durán, M Sepúlveda, M Pérez, L Rodríguez, W Stotz \& V Araos. 2003. Interferencia de mamíferos marinos con actividades pesqueras y de acuicultura. Informe Final Proyecto FIP 03-32: 1-216. Subsecretaría de Pesca, Valparaíso. <http://www.fip.cl/ Archivos/Hitos/Informes/inffinal\%202003-32.pdf>

Passadore C, A Domingo \& ER Secchi. 2015. Depredation by killer whale (Orcinus orca) and false killer whale (Pseudorca crassidens) on the catch of the Uruguayan pelagic longline fishery in Southwestern Atlantic Ocean. ICES Journal of Marine Science 72 <doi: 10.1093/icesjms/ fsu251>

Pizarro O, AJ Clarke \& S Van Gorder. 2001. El Niño sea level and currents along the South American coast: comparison of observations with theory. Journal of Physical Oceanography 31: 1891-1903.

Read AJ. 2008. The looming crisis: Interaction between marine mammals and fisheries. Journal of Mammalogy 89(3): 541548. 
Reyes P, R Hucke-Gaete \& JP Torres-Florez. 2013. First observations of operational interactions between bottomtrawling fisheries and South American sea lion, Otaria flavescens in south-central Chile. Journal of the Marine Biological Association of the United Kingdom 93: 489494.

Riedman M. 1990. The pinnipeds. Seals, sea lions, and walruses, 439 pp. University of California Press, Los Angeles.

Sepúlveda M, MJ Pérez, D Oliva, LR Durán, W Sielfeld, V Araos \& M Buscaglia. 2007. Operational interaction between South American sea lions Otaria flavescens and artisanal (small-scale) fishing in Chile: results from interview surveys and on-board observations. Fisheries Research 83: 332-340.

Sepúlveda M, D Oliva, A Urra, MJ Pérez-Álvarez, R Moraga, D Schrader, P Inostroza, A Melo, H Díaz \& W Sielfeld. 2011. Distribution and abundance of the South American sea lion Otaria flavescens (Carnivora: Otariidae) along the central coast off Chile. Revista Chilena de Historia Natural 84: 97-106.

Sepúlveda M, RA Quiñones, P Carrasco \& MJ PérezÁlvarez. 2012. Daily and seasonal variation in the haul-out behavior of the South American sea lion. Mammalian Biology 77(4): 288-292.

Sielfeld W, C Guerra, LR Durán, E Acuña, A Aguayo-Lobo, M Sepúlveda, F Palma, A Malinarich, G Cerda, A Bolvarán, R Grau, X Veloso, Y Guerra, M Vargas, N Amado, R Peredo \& J Galáz. 1997. Monitoreo de la pesquería y censo del lobo marino común en el litoral de la I-IV Regiones. Informe Final Proyecto FIP 95-28: 1-105. Subsecretaría de Pesca, Valparaíso. <http://www.fip.cl/ Archivos/Hitos/Informes/inffinal\%2095-28.pdf>
Sielfeld W. 1999. Estado del conocimiento sobre conservación y preservación de Otaria flavescens (Shaw, 1800) y Arctocephalus australis (Zimmermann, 1783) en las costas de Chile. Estudios Oceanológicos 18: 81-96.

Smith MH \& SJ Baird. 2005. Factors that may influence the level of incidental mortality of Hooker's sea lions (Phocarctos hookeri) in the squid (Nototodarus spp.) trawl fishery in SQU 6T. New Zealand Fisheries Assessment Report 2005: 35-56.

Soto KH, AW Trites \& M Arias-Schreiber. 2006. Changes in diet and maternal attendance of South American sea lions indicate changes in the marine environment and prey abundance. Marine Ecology Progress Series 312: 277-290.

Swartzman G, A Bertrand, M Gutiérrez, S Bertrand \& L Vasquez. 2008. The relationship of anchovy and sardine to water masses in the Peruvian Humboldt Current System from 1983-2005. Progress in Oceanography 79: 228-237.

Szteren D \& E Páez. 2002. Predation by southern sea lions (Otaria flavescens) on artisanal fishing catches in Uruguay. Marine and Freshwater Research 53: 1161-1167.

Venables WN \& BD Ripley. 2002. Modern applied statistics with S, 504 pp. Springer, New York.

Wickens $P$. 1995. A review of operational interactions between pinnipeds and fisheries. FAO Fisheries Technical Paper 346: 1-86.

Wolter K \& MS Timlin. 1998. Measuring the strength of ENSO-how does 1997/98 rank? Weather 53: 315-324.

Wood SN. 2008. Fast stable direct fitting and smoothness selection for generalized additive models. Journal of the Royal Statistical Society: Series B 70(3): 495-518.

Zuur A, E Ieno, NJ Walker, A Saveliev \& G Smith. 2009. Mixed effects models and extensions in ecology with R, 574 pp. Springer, New York. 